\title{
Emergence of multi drug resistant nonfermentative Acinetobacter spp in a tertiary care hospital
}

\author{
Shyamkuwar Amol ${ }^{1 *}$, Deogade Narendra ${ }^{2}$, Wadher Bharat ${ }^{1}$, Roychoudhury Kunal ${ }^{3}$ \\ From First International Science Symposium on HIV and Infectious Diseases (HIV SCIENCE 2012) \\ Chennai, India. 20-22 January 2012
}

\begin{abstract}
Background
Acinetobacter are gram negative, catalase positive, oxidase negative, nonmotile, non fermenting cocobacilli. The emergence of Acinetobacter infection is uncommon in organ systems that have a high fluid content. The nosocomial infections including, respiratory tract, CSF, peritoneal fluid, urinary tract, and endotracheal aspirtes (ET) are the place where they have the capabilities to accumulate and cause in-hospital and in-community infections. The rate of emergence of Acinetobacter spp with multi drug resistance property is increasing in different geographical regions. Due to the properties of MDR the recent treatments of such infections has become difficult. In the present study evaluation of emergence of MDR nonfermentative Acinetobacter spp was done from the niche of organ system of patients with high fluid content.
\end{abstract}

\section{Method}

The nonfermentative Acinetobacter spp were isolated from different clinical samples according to standard procedures and Gilardi schemes. The antibiotyping of Acinetobacter was done by disk diffusion method as per CLSI standards.

\section{Results}

$31.12 \%(62 / 193)$ of nonfermentative Acinetobacter spp were isolated from different clinical samples. The ratio of resistance against different antibiotics among Female: Male was found to be 1:1.38. All Acinetobacter spp were multi-resistant and showed different multi drug resistance pattern. Acinetobacter spp from samples showed varied resistance including, $60 \%$ resistant strain from

\footnotetext{
* Correspondence: amolshyamkuwar@rediffmail.com

${ }^{1}$ Post Graduate Teaching Department of Microbiology, RTM Nagpur

University, Nagpur-440033, India

Full list of author information is available at the end of the article
}

wound swabs, 50\% from Pus, 28-30\% from ET aspirates and blood.

\section{Conclusion}

Acinetobacter spp posing significant problem worldwide and increasingly responsible for numerous infections. Our study shows the emergence of high rate of MDR of Acinetobacter spp against 18 antibiotics belonging to different groups.

\section{Author details}

${ }^{1}$ Post Graduate Teaching Department of Microbiology, RTM Nagpur University, Nagpur-440033, India. ${ }^{2}$ Department of Microbiology, Indira Gandhi Government Medical College, Nagpur-440018, India. ${ }^{3} \mathrm{PG}$ Department of Microbiology, Seth Kesarimal Porwal College, Kamptee-441002, India.

Published: 4 May 2012

doi:10.1186/1471-2334-12-S1-P28

Cite this article as: Amol et al:: Emergence of multi drug resistant nonfermentative Acinetobacter spp in a tertiary care hospital. BMC Infectious Diseases 2012 12(Suppl 1):P28.

\section{Submit your next manuscript to BioMed Central and take full advantage of: \\ - Convenient online submission \\ - Thorough peer review \\ - No space constraints or color figure charges \\ - Immediate publication on acceptance \\ - Inclusion in PubMed, CAS, Scopus and Google Scholar \\ - Research which is freely available for redistribution

